\title{
Message from Vice-President \& Chairman, G.P. Committee
}

\section{Dear Fellow Members,}

Since addressing you in this page last year, an eventful year has passed in the life of your beloved Institution and, with all modesty, the past year was indeed a remarkable year for us with so many important achievements including the centre-stage events of HRD Ministry's Recognition of our AM-IIW as equivalent to Bachelor Degree in Engineering, and The International Welding Conference, IWC-2001.

Recently concluded at New Delhi (15-17th February, 2001), IWC-2001 was a gala event like IWC99 and over-whelming participation from abroad and homeland graced the proceedings. Advanced CD-Rom and Silk-Souvenir were distributed to all participants. However, Exhibition participation showed a downward trend, which may be due to the prevailing national industrial climate and so many overlapping exhibitions. The Organising Committee Team-work under the leadership of our President Mr. M. K. Mittal reached a high peak.

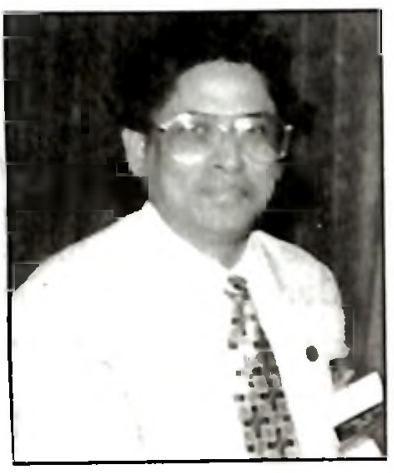

On 3rd March, 2001 the Institute's AGM was held at Calcutta in all solemnity. While most of the Office Bearers continued, Institute's installed its new Honorary Secretary Mr. A. K. Mukherjee. Our Best Wishes to him.

Your General Purpose Committee, in the 2nd year of its tenure has, as usual, drawn up a heap of activities and we seek your full co-operation and guidance so that they materialise, not only effectively but also in a timely manner.

We are happy to announce some activities already completed/nearing completion :

- Revised Branch Rules for Uniform System guiding all Branches.

- Membership Directory - A long-awaited Project now getting ready to be in your hand by this month end.

- Modalities for Uniform Study Centre to be organised by all Branches in the wake of HRD Ministry's Recognition.

- International \& National Co-operation in the Welding I.T. field is getting wings with IIW's own Web Home Page. Already discussions are on with WTI of Australia as well as some National Welding Web-Pages. It's heartening to report that you may take advantage of it (www.iiwindia.com) by advertising through one of its 10 advertisement slots.

- Expecting fresh surge of AM-IIW entrants to better their professional qualification. Desired Revamping of Examination System with Board of Studies. Finalising a panel of Examiners has already been taken in hand and fruits may come soon.

This year (2001) is going to be moderately-event-rich with National Welding Meet (tentatively at Mumbai) and Various International \& Afro-Asian Welding Conferences.

In the Space age, your National Headquarters is also gearing up to greet the New Millennium with e-mail/website facilities, upgraded computer facilities, comfortable working environment, on-line membership enrolment facilities etc.

Your official organ : IWJ is maintaining its tenure, standard as well as colourful get-up, thanks to the energetic Editor. However, a word of soul searching: it is at times failing to be self-financing and needs not only your concern and care but immediate co-operation with Advertisement, Technical Articles, Quizes etc.

Modernisation and adoptions are the key words for any institution if you wish to march forward. This has prompted your National Council to think for various ideas like Postal Ballots, Registration under Society's Act, Construction of Institution's own Building \& Training Centre. These are, surely, very ambitious dreams - but once we roll together, days are not far off when these may be within our reach, thus placing your Institution at par with its International counterparts.

Thoughts are provoking me to continue this intimate dialogue with my fellow members but space-constraints should humble me to end here. I shall wait for an opportunity in the near future to be again with you through this column.

Till then, wishing all the best to you, your family and your institutional family.

With best regards

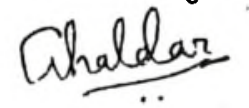

ANUPAM HALDAR

Vice-President \& Chairman, G.P. Committee. 